\title{
DOROTA BRYLLA
}

(Zielona Góra)

\section{BIBLIJNY OPIS STWORZENIA W NAUCZANIU BNEI BARUCH}

\section{Wprowadzenie. Organizacja Bnei Baruch i charakter proponowanego przez nią nauczania}

$\mathrm{Na}$ stronach poniższych odniosę się do wyłaniającej się z nauczania Bnei Baruch interpretacji biblijnych siedmiu dni stworzenia ${ }^{1}$. Decyduję się poświecić uwagę temu zagadnieniu, gdyż ujęcie przez członków Instytut Bnei Baruch opisu stworzenia z Księgi Bereszit (Księgi Rodzaju) jest radykalnie nieklasyczne, jest wręcz całkowicie antynomiczne względem interpretacji teologicznej ${ }^{2}$.

W istocie rzeczy członkowie Instytutu Bnei Baruch nie muszą dbać o zachowanie wierności wobec dyskursu teologicznego, otwarcie odcinają się bowiem od

\footnotetext{
1 Piszę siedmiu, a nie sześciu, gdyż siódmy dzień, w którym - zgodnie z zapisem Biblii „Bóg odpoczął”, jest zwieńczeniem dzieła Bożego, nieodłączonym od „aktywnych” dni procesu kreacji.

2 O znaczeniu biblijnych dni kreacji i mistycznym charakterze opisu stworzenia z Księgi Rodzaju nie pisze się jednak w pracach Bnei Baruch wiele. Ze znanych mi tekstów grupy in extenso traktuje o tym: Michael Laitman, Semion Winokur, Odkrycie tajemnic Biblii. Od stworzenia do Abrahama (http://files.eurokab.info/pl/Odkrycie\%20tajemnic\%20Biblii-1.pdf). Poza nim wzmianki na ten temat znajdują się w: Michael Laitman, The Path of Kabbalah, transl. Chaim Ratz, Laitman Kabbalah Publishers, Toronto 2005. W końcu, zagadnieniu temu poświęcono uwage $\mathrm{w}$ broszurze Michaela Laitmana pt. The Secret Meaning of the Bible: Seven Days of Creation (http://www.kabbalah.info/eng/content/view/frame/2373?/eng/\&main). Najnowszą pracą (wydaną w październiku 2014 r.) jest książka: Michael Laitman, Disclosing a Portion: The Inner Mechanics of the Torah, transl. Chaim Ratz, Laitman Kabbalah Publishers, Toronto 2004. W całości traktuje ona o wykładni Bnei Baruch ksiąg Tory, przy czym samemu opisowi stworzenia w siedmiu dniach poświęca się tu znikome miejsce. Z uwagi na powyższe okoliczności bibliografia z konieczności będzie ograniczona.
} 
religii, zarówno jeśli chodzi o doktrynę (co najbardziej zastanawiające, zważywszy chociażby na podejmowanie i wyjaśnianie kategorii biblijnych), jak i kult czy organizację $^{3}$. Wszelako wydaje się, że owo odgradzanie się od religii oraz religijności i ukazywanie swojego nauczania jako stojącego w jawnej antytezie do religii i teologii jest nie do końca uzasadnione, w nauczaniu tym bowiem (powiedziałabym mocniej: wręcz doktrynie - co już samo to może nieść konotacje religijne), swoistym belief system, nie tylko widać zespół twierdzeń, czy tė̇ przekonań o rzeczywistości duchowej, co jako takie jest doktryną właśnie (i stawiam tezę, że doktryną religijną lub religijno-filozoficzną/teologiczno-filozoficznąa ${ }^{4}$, a nie doktryną naukową - jak sami członkowie Bnei Baruch twierdzą ${ }^{5}$ ) - czyli naczelnym elementem systemu religijnego - ale i sama ta doktryna buduje na terminach, ideach i całych koncepcjach de facto judaizmu, a więc religii (żydowskiej) ${ }^{6}$. Nota bene, pełna nazwa Instytut Bnei Baruch brzmi „Instytut Studiów i Badań Kabały Bnei Baruch", a kabała to (w prawidłowej, tj. religijnej i akademickiej wykładni) mistycyzm żydowski, ezoteryczno-mistyczna gałąź judaizmu, mistyczno-filozoficzna szkoła judaizmu.

W tym miejscu warto pokrótce przedstawić organizację Bnei Baruch. Została ona założona w 1991 roku przez - określanego przez uczniów rawem („nauczycielem") - Michaela Laitmana (ur. 1946). Nazwa organizacji, dosłownie „Synowie Barucha”, pochodzi od Barucha Szaloma ha-Lewi Aszlaga (1906 lub 1907-1991) - nauczyciela i mentora Laitmana, jednego z kabalistów, na których

3 Zgodnie z trychotomiczną definicją religii zaproponowaną przez klasyka religioznawstwa i socjologa religii Joachima Wacha (zob. tenże, Socjologia religii, przeł. Zygmunt Poniatowski, Bogusław Wolniewicz, Książka i Wiedza, Warszawa 1961, s. 48-60).

4 W moim odczuciu najpoprawniej jest mówić o właściwej systemowi Bnei Baruch ontoteologii (termin biorę za Martinem Heideggerem; zob. tenże, Identität und Differenz, Günther Neske, Pfullingen 1957) [wyd. polskie: Identyczność i różnica, przeł. Janusz Mizera, Wydawnictwo Aletheia, Warszawa 2010) lub teoontologii (termin biorę za: Mieszko Ciesielski, Pomiędzy teizmem i ateizmem. O Bogu, który byl, „Humaniora. Czasopismo Internetowe”, nr 2(6)/2014, s. 29, 31). Odnoszę ontoteologię oraz teoontologię do dziedziny spekulacji, w której przedmiotem zainteresowania jest struktura Boskiego Bytu (tym samym zmieniam nieco rozumienie teoontologii wybrzmiewające z pracy Ciesielskiego, który mówi o „ujęciu teoontologicznym” i „sytuacji teoontologicznej” w kontekście stawiania pytania o istnienie Boga). Ja posługuję się terminami „ontoteologia" oraz „teoontologia” jako swoistymi synonimami dla wyrażenia „ontologia [na temat] Boga" - „sama” ontologia w sytuacji doktryny Bnei Baruch wydaje się terminem niewystarczającym, zważywszy na teologiczne (jakkolwiek ujęte mocno specyficznie) cechy tego systemu. $\mathrm{Na}$ temat teoontologii i ontoteologii por. Zdzisław Kunicki, Teo-ontologia wobec onto-teologii. Étienne Gilsona metafizyka „Księgi Wyjścia” na tle wspólczesnych sporów teistycznych, Studio Poligrafii Komputerowej „SQL”, Olsztyn 2004.

5 W nauczaniu Bnei Baruch wielokrotnie pojawiają się wszak tezy w stylu: Kabala jest nauka [science] o strukturze Wyższego świata (zob. np. M. Laitman, The Secret Meaning of the Bible: Seven Days of Creation, art. cyt. [19.11.2014]).

6 Wnikliwy badacz będzie w stanie dopatrzyć się i elementów swoiście kultycznych oraz organizacyjnych światopoglądowej propozycji Bnei Baruch. Nie ma tu jednak miejsce na poruszanie tego wątku. 
w swoim nauczaniu opiera się Bnei Baruch 7 . Baruch był synem i następcą Jehudy Leib ha-Lewi Aszlaga (1886-1954), noszącego przydomek Baal ha-Sulam ${ }^{8}$

Według samego Laitmana, a w ślad za nim także według jego sympatyków, stowarzyszenie rozpowszechnia nauki kabały, tj. [...] madrość kabały w celu przyspieszenia uduchowienia ludzkości ${ }^{9}$. Nie jest to jednak kabała rozumiana klasycznie (nie jest to mistycyzm/ezoteryzm żydowski). Sposób potraktowania kabały, tzn. wypracowana przez Bnei Baruch specyficzna interpretacja pewnych stricte kabalistycznych (tj. z łona mistycznej myśli żydowskiej) pojęć i kategorii oraz sama metoda jej studiowania, pojmowania i przekazywania, oparta jest w całości na podejściu wypracowanym przez Aszlagów i Laitmana. Organizacja buduje na wykładni kabały Aszlagów, gdyż to ona ma być najlepiej dostosowana do dzisiejszych czasów i mentalności współczesnych ludzi ${ }^{10}$. Tym zresztą kabała Bnei Baruch różni się też od kabały żydowskiej - o ile ta druga miała wybitnie ezoteryczny i ekskluzywny charakter, o tyle ta pierwsza jest egzoteryczna i inkluzywna, skierowania wprost do ludzi, sama do nich ze swoją nauką „wychodząca”.

Organizacja Bnei Baruch jest organizacją non-profit, społecznością złożoną z ludzi zamieszkujących na całym świecie (są oni tzw. studentami kabały). Międzynarodowy charakter stowarzyszenia możliwy jest dzięki aktywności prowadzonej przez Instytut za pomocą internetu, przy czym centrum organizacji mieści się w Izraelu. Silnie rozwinięta jest amerykańska społeczność Bnei Baruch. Istnieje również polska grupa „Synów Barucha”.

Analizując teksty Bnei Baruch nie trudno zauważyć, że wyłaniające się z nich nauczanie zawiera in nuce pewne wątki i koncepcje religii mojżeszowej - judaizmu ortodoksyjnego i kabały (judaizmu mistycznego) ${ }^{11}$. Jednym z takich zapożyczeń z doktryny judaizmu jest opis stworzenia świata w siedmiu dniach, zawarty w pierwszych wersetach Tory (Starego Testamentu chrześcijan), mianowicie w Księdze Rodzaju (Księdze Genesis, Pierwszej Księdze Mojżeszowej, Księdze Bereszit [dosłownie z hebrajskiego: Księga Początku]). Już sam ten fakt

7 About Bnei Baruch, http://www.kabbalah.info/engkab/abouteng.htm (03.04.2011).

8 Hebr. sulam = 'drabina'. Jehuda był autorem komentarza do kabalistycznej Sefer ha-Zohar, zatytułowanego właśnie Sulam.

9 Michael Laitman, Kabała ujawniona. Jak doprowadzić nas do świata pokoju, harmonii i ekorozwoju, przeł. Anna Wojtaszczyk, Warszawa, Studio Emka 2009, s. 184.

10 Zob. np. tenże, The Kabbalah Experience, transl. David Brushin, Chaim Ratz, Laitman Kabbalah Publishers, Toronto 2005, s. 446.

11 Przy czym tutaj jedna uwaga. Nieprawidłowe jest spotykane niekiedy określanie kabały (żydowskiej, czyli mistycyzmu żydowskiego, ezoteryzmu żydowskiego) ruchem heterodoksyjnym czy heretyckim. Kabała bowiem nigdy nie została przez przedstawicieli żydowskiego prawa uznana za doktrynę heretycką, schizmatycką - jakkolwiek jest to nauczanie ezoteryczne względem egzoterycznych, powszechnych twierdzeń judaizmu (zob. na ten temat Charles Mopsik, Kabala, przeł. Adam Szymanowski, Wydawnictwo Cyklady, Warszawa 2001, s. 31-32). 
- to znaczy interpretowanie tekstu świętej księgi judaizmu (szerzej: judeochrześcijaństwa) - zdaje się świadczyć o, w jakiejś mierze przynajmniej, religijnym charakterze ruchu.

\section{Podejście Bnei Bruch do tekstu biblijnego}

W interpretacji opisu biblijnego członkowie Bnei Baruch porzucają egzegetyczny poziom Pszat (poziom znaczenia literalnego) ${ }^{12}$ - który jest, jak twierdzi grupa, niewystarczający, pozostawia bowiem wiele pytań bez odpowiedzi; jest nielogiczny i nienaukowy - na rzecz mocno niedosłownego ${ }^{13}$, mistycznego sposobu analizy (twierdzi się, że księgi święte mówią wyłącznie o rzeczywistości duchowej i o tym, jak z tzw. duchowego ${ }^{14}$ pochodzi świat materialny, doczesny), który to

12 Pszat jest jedną z czterech metod egzegetycznych (rozumienia i interpretacji) pisma świętego w judaizmie (co jest, jak uważam, ponownie i tu jednym z wyznaczników religijnego i teologicznego charakteru ruchu i nauczania Bnei Baruch). Pozostałe metody egzegezy to: remez, drasz i sod. Owe cztery metody łącznie określa się akronimem PARDES (zob. np. Alan Silver, Jews, Myth and History: A Critical Exploration of Contemporary Jewish Beliefs and Its Origins, Matador, Leicester 2008, s. 33). Wydaje się, że członkowie Bnei Baruch posługują się metodą sod - uwypuklającą znaczenie ezoteryczne, mistyczne (nomen omen kabalistyczne) analizowanego tekstu (tym bardziej, że metodę sod stosuje się zasadniczo dla pierwszego rozdziału Bereszit [sic!; zob. Leo Schaya, The Universal Meaning of the Kabbalah, transl. Nancy Pearson, Penguin Books, Baltimore, Maryland 1973, s. 18]), przy czym 1) nie znalazłam stwierdzenia explicite, że taki sposób interpretacji jest przez członków ruchu używany (przypuszczalnie wynika to z chęci zachowania linii demarkacyjnej pomiędzy własnym nauczaniem a nauczaniem religijnym, czyli po prostu, i znowuż tu, odcięcia się od religii w ogóle), 2) sama owa kabalistyczna metoda egzegezy jest mocno odległa od klasycznie rozumianej interpretacji kabalistycznej, gdyż także kabała - jako historyczna forma mistycyzmu żydowskiego - posiada właściwe sobie modusy interpretacyjne i pewne ogóle wytyczne oraz założenia co do mistycznego rozumienia konkretnych idei i koncepcji judaizmu. Powyższe potwierdza zresztą wysoce nieklasycznie „kabalistyczny” charakter kabały Bnei Baruch względem kabały „normatywnej”.

13 Warto wspomnieć, że na nieliteralny sposób egzegezy biblijnego opisu stworzenia napotkać można co jakiś czas - i to także, co ciekawe, w ramach ortodoksyjnego judaizmu. Dosłowna interpretacja upatruje w dniach stworzenia 24-godzinne odcinki czasu, a niedosłowna - lub też lepiej: pozornie dosłowna (ostensibly literal) - ogromne epoki czasu (swoiste kosmiczne epoki). Za reprezentanta tego ostatniego podejścia uchodzi np. Nathan Aviezer - autor piszący note bene z perspektywy konkordyzmu (postulującego istnienie zgodności pomiędzy tym, co orzekaja twierdzenia religijne a odkryciami współczesnej nauki). Według Aviezera sześć dni stworzenia to sześć faz rozwoju Wszechświata: począwszy od Big Bangu „dnia pierwszego”, skończywszy na powstaniu człowieka jako korony stworzenia w „dniu szóstym” (występuje tu zatem, jak zauważa Robert Piotrowski w recenzji innej książki Aviezera, mianowicie Fossils and Faith: Understanding Torah and Science (KTAV Publishing House, Inc, New Jersey: Hoboken, 2001), argument z domniemanej nietożsamości czasu Bożego i ludzkiego [zob. Robert Piotrowski, Tora $i$ nauka wedlug Aviezera, Filozoficzne Aspekty Genezy, 2012, t. 9, s. 278, http://www.nauka-a-religia.uz. zgora.pl/images/FAG/2012.t.9/art.11.pdf]). Aviezer wyniki swoich analiz dotyczących Boskiej kreacji w sześciu dniach zawarł w pracy: tenże, In the Beginning: Biblical Creation and Science, KTAV Publishing House, Inc, New Jersey: Hoboken, 1990.

14 Takiego terminu się w istocie używa; zob. jedyną książkę ruchu wydaną w języku polskim: M. Laitman, Kabała ujawniona. Jak doprowadzić nas do świata pokoju, harmonii i ekorozwoju, dz. cyt. 
sposób pozwala człowiekowi widzieć świat we właściwy, niezaburzony sposób ${ }^{15}$. Mówi się nam poza tym, że Doktora Laitmana niezwykła interpretacja historii [starotestamentowych, o czym wcześniej - ...] opiera sie na prawdach odkrytych w Księdze Zohar, która zawiera tajemnice Tory. Tajemnice te odkrywaja głęboki $i$ bardzo osobisty poziom tych opowieści, zaopatrujac nas w nowe narzędzia zrozumienia naszego własnego życia $i$ życia tych, których kochamy ${ }^{16}$.

Tezą stawianą przez Instytut Bnei Baruch jest, że tekst z Księgi Rodzaju, jak i każdy inny tekst z Tanachu (które traktowane są jako nomen omen teksty kabalistyczne), nie opisuje materialnego świata. Opis ów nie dotyczy ziemskich wydarzeń (skąd też będzie, że „dzień” nie oznacza doby mierzonej od wschodu do zachodu słońca ${ }^{17}$ ), za to traktuje o tym, co wydarza się w ,światach wyższych", w „duchowym” (rzeczywistości duchowej, światach duchowych) ${ }^{18}$. Pisma kabalistyczne (do których poza księgami Tanachu członkowie Bnei Baruch włączają jeszcze Sefer Jecira [Ksiega Stworzenia], Sefer ha-Zohar [Ksiega Blasku], pisma Izzaka Lurii, Jehudy Aszlaga, Barucha Aszlaga oraz Michaela Laitmana) tylko na poziomie powierzchownym zdają się być związane ze światem doczesnym. $\mathrm{W}$ istocie jednak słowa te (zapis ksiąg) mają odnosić się do „wyższej” rzeczywistości, do tzw. korzenia, a przyjmują postać semantyczną poznawalną dla ludzi, możliwą przez nich do odczytania. Idea ta - z pewnej perspektywy bliska, jak sądzę, platonizmowi - nosi nazwę „korzeń i gałęzie”, a język kabalistyczny, zatem i ten zastosowany w Biblii, to „język gałęzi”. Jako że każdy obiekt materialny lub siła odpowiada obiektowi duchowemu lub sile, która tym pierwszym kieruje, tworzy się maksymalnie ścista zgodność pomiędzy nazwa wzięta ze świata materialnego i jej duchowym korzeniem, jej źródłem ${ }^{19}$.

Szersze swoje odniesienie idea powyższa znajduje wyraz w ontologicznym przekonaniu, że (boski, duchowy) „korzeń” jest przyczyną tego, co wydarza się w świecie (skutek-,gałąź"). Gałęzie czerpią z korzeni tak, jak (u Platona) rzeczy (u Bnei Baruch „gałęzie”) partycypują w ideach (u Bnei Baruch w „korzeniu"). Wydaje się także, że w odniesieniu do nauczania Bnei Baruch można mówić i o pewnym podobieństwie do neoplatonizmu, w tym ostatnim bowiem - poprzez

15 Zob. tenże, The Secret Meaning of the Bible: Seven Days of Creation, art. cyt. (23.11.2014).

16 Tenże, Disclosing a Portion: The Inner Mechanics of the Torah, wyd. cyt., s. 7 (Introduction).

17 Nie ma to nic wspólnego z siedmioma ziemskimi dniami; nie odnosi się ani do dnia i nocy, ani światta $i$ ciemności na ziemi. Dotyczy [natomiast] stanów duchowych i odczuć duchowych kogoś, kto przeszedl te stany naprawy. Mówi o systemie, w którym ludzka dusza naprawia się, będac na poziomie zwanym „ziemia”; tenże, The Secret Meaning of the Bible: Seven Days of Creation, art. cyt. (23.11.2014).

18 Zob. tamże (23.11.2014).

19 Michael Laitman, Basic Concepts in Kabbalah: Expanding Your Inner Vision, transl. David Brushin, Laitman Kabbalah Publishers, Toronto 2006, s. 21. 
właściwy mu emanatyzm i egzemplaryzm - orzeka się o „wzorcu” (idea) i „odbitce” (w kabale: „korzeń” - „gałęzie”), a struktura świata odbija relacje urzeczywistnione w sposób doskonały w boskim pierwowzorze ${ }^{20}$ (które to przekonanie odnaleźć można i u Bnei Baruch).

\section{Centralne kategorie nauczania Bnei Baruch i ich rola w egzegezie biblijnego opisu stworzenia}

Niezwykłość wykładni Bnei Baruch pierwszych wersów Tory traktujących o kosmogonii polega na włączeniu w tę wykładnię dwóch fundamentalnych dla nauczania Instytutu kategorii (będących kategoriami swoiście filozoficzno-psychologicznymi) - tzw. chęci obdarowywania i chęci otrzymywania. Sama Tora w pierwszym rozdziale ${ }^{21}$ mówić ma tak naprawdę o stworzeniu chęci otrzymywania, zwanej duszą ${ }^{22}$ lub Adamem ${ }^{23}$. Chęć obdarowywania natomiast to Stwórca, Bóg ${ }^{24}$. Stwórca oznacza w doktrynie Bnei Baruch siłę altruistyczną, „dawanie”, miłość. Chęć otrzymywania z kolei to całość stworzenia - z człowiekiem jako jego kulminacją ${ }^{25}$. Człowieka określa egoizm, pożądania i pragnienia (które pozostają wiecznie niezaspokojone; zaspokojenie jednego pragnienia zawsze wywołuje bowiem powstanie kolejnego, silniejszego pragnienia). Człowiek (chęć otrzymywania) i Stwórca (chęć obdarowywania) to dwa przeciwległe bieguny. Celem człowieka i jego życia jest jednak osiągnięcie stanu Stwórcy, to jest osiągniecie „równoważności formy z Nim" 26 - osiągnięcie stanu, w którym człowiek bezinteresownie daje (obdarowuje), czyli czyni to, co Stwórca ${ }^{27}$. Chodzi więc o naprawę (tikkun)

20 Zob. Stefan Swieżawski, Dzieje filozofii europejskiej XV wieku. Tom IV: Bóg, Collectanea Theologica, Warszawa 1979, s. 358.

21 A wręcz w całej księdze Bereszit; zob. M. Laitman, Disclosing a Portion: The Inner Mechanics of the Torah, wyd. cyt., s. 9.

22 Dusza, która powstaje, jest jedną (wszech)duszą, na którą składają się dusze poszczególnych ludzi.

23 Adam w nauczaniu Bnei Baruch to wspólna dusza i tyle co „pragnienie”. Nie jest to byt materialny.

24 W doktrynie Bnei Baruch słowo „Bóg” praktycznie nie pojawia się - występuje termin „Stwórca”, ale zakres znaczeniowy ma wspólny z pojęciem „Bóg”.

25 Ogół stworzenia to też synonim dla Adama. Adam jest całością ludzkich dusz, jedynym „bytem”, który istnieje. I jako taki jest właśnie „pragnieniem” (por. przyp. 23 niniejszego artykułu) - bo stworzenie w całości określane jest przez pragnienie.

26 Zob. dla przykladu: Michael Laitman, A Guide to the Hidden Wisdom of Kabbalah, Laitman Kabbalah Publishers, Toronto 2009 (3rd edition), s. 44, 178, 191, 196; tenże, Kabbalah for Beginners, Laitman Kabbalah Publishers, Toronto 2007 (4th edition), s. 101, 109, 147-148, 165.

27 Jak mówi się nam: Cała praca czlowieka, ze względu na która się rodzi, polega na otrzymaniu 
ludzkiego egoizmu, o naprawę swoich pragnień - co da i naprawę świata w ogóle (tikkun olam ${ }^{28}$, wszak Wszystko, co sie dzieje w naturze, jest odbiciem tego, co dzieje sie wewnatrz człowieka ${ }^{29}$. Oddzielenie swoich właściwości egoistycznych od altruistycznych ma zjednoczyć, tj. zrównoważyć, człowieka ze Stwórcą, a przez to z całym światem ${ }^{30}$.

To ów proces wewnętrznej naprawy przedstawiony został według Bnei Baruch w zapisie Księgi Rodzaju. Siedem dni stworzenia to stopnie naprawy: Cała naprawa odbywa się w ciagu siedmiu twoich stanów zwanych „siedmioma dniami”.

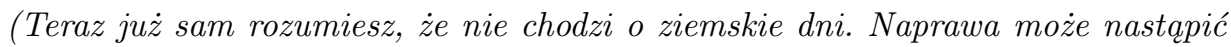
$w$ jednej chwili, w ciagu roku, długich lat, całego życia lub wielu obrotów życia - wszystko zależy tylko od ciebie ${ }^{31}$ ), gdzie „dalsze” dni wskazują na trudniejsze, „cięższe” pragnienia, które należy przezwyciężyć. Zapis Tory pokazywać ma, co człowiek robić powinien ze swoją duszą w kolejnych krokach („dniach”) na$\operatorname{prawy}^{32}$.

Sześć dni stworzenia/stopni naprawy określanych jest w nauczaniu Bnei Baruch też jako sześć sefirot (l.poj. - sefira) o nazwach: Chesed, Gwura, Tiferet, Necach, Hod, Jesod. Sam termin sefira (sefirot) wywodzony jest od hebrajskiego słowa sapir: 'świecenie', 'jarzenie', 'iluminacja'33, co potrzebne jest dla tutejszej idei, że każdy stopień naprawy (więc dzień) ma swoje światło ${ }^{34}$, iluminację ${ }^{35}$.

właściwości Stwórcy, właściwości obdarzania. Za jej pomoca naprawia on siebie $i$ w miarę naprawy wznosi się coraz wyżej po duchowej drabinie ku doskonalości i nieskończoności, zbliżajacc się coraz bliżej do Stwórcy (M. Laitman, Odkrycie tajemnic Biblii. Od stworzenia do Abrahama, wyd. cyt., s. 32).

28 Tikkun jest klasycznym pojęciem kabalistycznym, oznaczającym „naprawę”, przy czym występuje ono już w Misznie jako „zachowywanie ustalonego porządku”. Wyrażenie tikkun olam (,świat naprawiony") pojawia się np. w jednej z żydowskich modlitw z czasów talmudycznych, gdzie oznacza „doskonalenie świata pod panowaniem Boga”; zob. Howard Schwartz, How the Ari Created a Myth and Transformed Judaism, http://www.tikkun.org/nextgen/how-the-aricreated-a-myth-and-transformed-judaism (25.11.2014).

29 M. Laitman, Odkrycie tajemnic Biblii. Od stworzenia do Abrahama, dz. cyt., s. 30. Stąd też pojawia się cały program społeczny Bnei Baruch, pragnący odnowić społeczeństwo oraz zaprowadzić pokój i harmonię na świecie (zob. tytuł polskiej pracy: M. Laitman, Kabała ujawniona. Jak doprowadzić nas do świata pokoju, harmonii $i$ ekorozwoju, wyd. cyt.).

30 Widać stąd, że Stwórca to swoista kategoria panteistyczna - równoważna jest bowiem przyrodzie, całości ontycznej (w kabale Bnei Baruch podkreśla się zresztą identyczność gematryczną słów „Bóg” i „przyroda” [wartość równa 86]; zob. np. Michael Laitman, Kabbalah, Science and the Meaning of Life, transl. Chaim Ratz, Laitman Kabbalah Publishers, Toronto 2006, s. 179).

31 Tenże, Odkrycie tajemnic Biblii. Od stworzenia do Abrahama, wyd. cyt., s. 18.

32 Zob. tenże, The Secret Meaning of the Bible: Seven Days of Creation, art. cyt. (23.11.2014).

33 Zob. tenże, Odkrycie tajemnic Biblii. Od stworzenia do Abrahama, wyd. cyt., s. 32.

34 Kategoria światła jest u Bnei Baruch bardzo ważna - pojawiają się tu takie podkategorie jak or hozer („światło powracające”), or makif („światło otaczające”), or pnimi („światło wewnętrzne") - wszystkie odnoszą się do procesu przyjmowania i oddawania (otrzymywania i obdarowywania).

35 Etymologicznie zaś termin sefirot konotuje 'liczby', 'wyliczenia' (pochodzi od hebrajskiego 
Sefirot jest dziesięć, powyższych sześć zasocjowanych z aktywnymi dniami stworzenia to sefirot dolne (od czwartej do dziewiątej) ${ }^{36}$. Sefirot ujmowane są przez system Bnei Baruch także jako części obejmującego stworzenie pragnienia (wówczas wprzęga się w tę interpretację trzy górne sefirot: Keter, Chochma, Bina, sefire szóstą: Tiferet oraz ostatnią dziesiątą: Malchut) ${ }^{37}$.

Centralne dla nauczania Bnei Baruch kategorie egoizmu i altruizmu pojawiają się przy interpretacji już pierwszego zdania Księgi Rodzaju: Na poczatku [hebr. bereszit] stworzył Bóg niebo i ziemie (1:1) ${ }^{38}$. Cecha egoizmu wiązana jest z ziemią, a altruizmu z niebiosami ${ }^{39}$. Ta pierwsza za pomocą tej drugiej może zostać przezwyciężona - proces ten opisany został za pomocą kategorii dni stworzenia. Pojęcie bereszit ( „na początku”) oznacza początek stwórczego procesu, a także w perspektywie antropologicznej - początek „dystansowania się” od przyrodzonej stworzeniu właściwości egoistycznej. Słowo bereszit wywodzone jest tu od bar - 'na zewnątrz' ${ }^{40}$. Sformułowanie takie oznacza, jak sądzę, że Stwórca wydziela z siebie (na zewnątrz) część, w której pojawi się stworzenie, a w końcu człowiek, który niezależnie i na mocy wolnej decyzji będzie chciał do Stwórcy powrócić ( „zrównoważyć swoją formę z Nim”) ${ }^{41}$.

Idea powyższa ma istotne konsekwencje dla dyskusji filozoficzno-teologicznej, bowiem 1) nie zachodzi tu stworzenie ex nihilo (a tak klasycznie rozumiane jest

rdzenia ר-פ [ $[$ [-f-r], tworzącego słowa safar - 'liczyć', 'wyliczać' oraz sifra - 'cyfra'). W klasycznej kabale sefirot są aspektami, hipostazami, przejawami, atrybutami, siłami Boga (Boga w wymiarze Ein-Sof ['nieskończone'], Boga teologii negatywnej).

36 W kabale żydowskiej te sefirot niższe/dolne (tzw. zajin tachtonot [zajin jest hebrajską literocyfrą, która w aspekcie cyfry wynosi siedem, a niższe sefirot występują w liczbie siedmiu) określane są jako „pałac dolny” (w przeciwieństwie do „pałacu górnego”, którym są trzy najwyższe sefirot: Keter, Chochma, Bina), a także nazywane są sefirot ha-binjon (,sefirot stworzenia/konstrukcji") - to ostatnie określenie pozostaje ważne w kontekście przeprowadzanych w niniejszej pracy analiz.

37 Zob. M. Laitman, The Secret Meaning of the Bible: Seven Days of Creation, art. cyt. (23.11.2014).

38 Cytaty z Księgi Rodzaju za wydaniem: Bereszit/Genesis, przeł. Izaak Cylkow, Kraków 1895.

39 W tym miejscu może nasuwać się pytanie, jak mogła istnieć cecha egoizmu bez jej „nośnika”, tj. człowieka (który powstanie dopiero „dnia szóstego”) - skoro to człowiek, i stworzenie jako takie, określane jest przez egoizm, chęć otrzymywania. Należy jednak zauważyć, że w wykładni Bnei Baruch Księgi Bereszit człowiek (gatunkowo ujęty) nie powstaje dnia szóstego - tego „dnia” (na tym etapie naprawy) człowiek osiąga szczyt procesu naprawy, i jako taki nazywany jest właśnie „człowiekiem”. Opis stworzenia jest dla Bnei Baruch metaforycznym ujęciem procesu tikkun, który przechodzi człowiek - ten zatem już istnieje. Z kolei idea istnienia „na początku” chęci obdarowywania, altruizmu, jest sensowna, skoro właściwość ta utożsamiana jest ze Stwórcą - wyprzedzającym wszelki czas (istniejącym przed „dziełem stworzenia”).

40 Zob. M. Laitman, The Secret Meaning of the Bible: Seven Days of Creation, art. cyt. (23.11.2014).

41 Twierdzi się ponadto: Aby umożliwić strukturze duszy stać się stworzeniem, musi ona zostać umieszczona na zewnatrz $i$ wycofana ze Stwórcy. Inaczej mówiac, musi ona zostać uczyniona przeciwna do Stwórcy, $i$ to przeciwieństwo uzyskiwane jest poprzez grzech (tenże, Disclosing a Portion: The Inner Mechanics of the Torah, wyd. cyt., s. 10). 
stworzenie opisane w Księdze Bereszit), 2) koncept ten pozostaje w pewien sposób bliski fundamentalnej koncepcji klasycznej kabały, mianowicie cimcum (dosłownie 'skurczenie się', 'ściśnięcie', 'kontrakcja') 42, którą XVI-wieczny kabalista Izaak Luria - nota bene kabalista, na którego powołują się członkowie Bnei Baruch zrozumiał jako „wycofanie się”: Boga z siebie, czyli właśnie wydzielenie w sobie wolnej przestrzeni, co umożliwiło zajście procesów stwórczych prowadzących do powstania wyodrębnionego bytu (wszechświata i w konsekwencji człowieka), mogącego istnieć równolegle do samego Stwórcy. Powodem, dla którego Stwórca, czyli czysta chęć obdarowywania, czyni to wszystko, jest pragnienie, aby stworzenie (tu: człowiek) świadomie i w sposób nieprzymuszony powrócił do swojego źródła.

\section{Organizacji Bnei Baruch interpretacja biblijnych dni stworzenia}

\section{a) dzień pierwszy}

Na początku stworzył Bóg niebo i ziemię. Ziemia zaś była zamętem $i$ bezładem, a ciemność nad otchtania; a duch Boży unosit się nad powierzchnia wód. I rzekt Bóg: „Niech sie stanie światło!” I stało sié światło. I widział Bóg światło, ze dobre; $i$ rozdzielit Bóg między świattem a ciemnościa. I nazwał Bóg światło dniem, a ciemność nazwał noca. I był wieczór i był ranek - dzień jeden. ( $\operatorname{Rdz} 1: 1-1: 5)$. Fragment ten według Bnei Baruch mówić ma o powstaniu atrybutu z przeciwległego kontinuum do Stwórcy - powstaje chęć otrzymywania. Jest nią ziemia, zwana też (sefira) Malchut. Jest to wszystko, co związane pozostaje z ziemskimi pragnieniami, z egoizmem. Pierwszego dnia zachodzi też stworzenie świata wyższego - miejsca, w którym zamieszkiwać ma ludzka dusza ${ }^{43}$. Owo miejsce określane jest jako sefira Bina, „Wyższa Matka” ${ }^{44}$, i jest nim niebo. Niebo jednoznaczne jest z właściwością altruistyczną. Pomiędzy tymi biegunowymi jakościami unosi się ludzka dusza.

\footnotetext{
42 Słowo to - wskazujące na coś, czego dostępuje żydowski Bóg - pojawia się już w midraszach.

43 Zauważmy, że mówi się tu o ludzkiej duszy. W standardowej interpretacji pierwszych wersów Księgi Stworzenia ludzka dusza, jako niematerialna część człowieka, powstaje dnia szóstego kiedy Bóg stwarza człowieka.

44 Zob. M. Laitman, Odkrycie tajemnic Biblii. Od stworzenia do Abrahama, wyd. cyt., s. 11. Określenie „Wyższa Matka” jest w klasycznej kabale jednym z podstawowych tytułów charakteryzujących trzecią sefire - Binę właśnie. Jakość ta w systemie Bnei Baruch równoznaczna jest z chęcią obdarowywania (siłą altruizmu), a więc z samym Stwórcą. „Wyższa Matka”, a więc Bina, a więc Stwórca, to docelowe miejsce ludzkiej duszy (człowieka), jednocześnie miejsce, z którego ona pochodzi.
} 
„Ziemia” z przytoczonych wersetów - w języku hebrajskim erec-pochodzić ma od hebrajskiego terminu racon, oznaczającego 'pragnienie' 45 . Ziemia to zatem pragnienie. Pragnienie jest w perspektywie Bnei Baruch wszystkim, co istnieje - całość stworzenia ziemskiego określana jest przez chęć otrzymywania. Boskie światło z kolei (Rdz 1:3: I rzekt Bóg: „Niech się stanie światto!” I stało się światło) to jedyna właściwość, która otaczać ma ludzkie dusze i świat w ogóle. Werset 1:4 (I widziat Bóg światto, ze dobre; i rozdzielit Bóg między świattem a ciemnościa) ma explicite mówić o pierwotnym rozdzieleniu dopiero co powstałych dwóch stanów-właściwość: obdarowywania („światło”) i otrzymywania („ciemność”). „Dzien" / „ranek” i „noc”/,wieczór”, które powstają (Rdz 1:5), to dwa stany, które tworzą się wewnątrz człowieka (odpowiednio: altruizm i egoizm). Rozdzielenie, odgraniczenie ich w sobie to pierwsze zadanie człowieka (pierwszy stopień naprawy, czyli „dzień pierwszy”).

Dzień pierwszy jest więc - w perspektywie antropologicznej - pierwszym krokiem w kierunku tikkun. Dla człowieka oznacza to, że powinien on zdać sobie sprawę, poczuć, że istnieje Stwórca, światło - siła obdarzająca. Pierwszy dzień oznacza rozpoznanie i oddzielenie przez człowieka myśli, odczuć i pożądań „czystych” (niebo) od „nieczystych” (ziemia) - który to proces zwany jest Akarat haRa („,rozpoznanie zła”) ${ }^{46}$. Rozpoznanie, które właściwość są czysto ludzkie (ziemskie), a które pochodząc od Stwórcy (duchowe), oraz pragnienie pokonania przyrodzonego człowiekowi egoizmu, to pierwszy krok w naprawie.

W kolejnych dniach stworzenia (poza szóstym i siódmym) Tora opisywać ma tworzenie przez Stwórcę duchowych sił, tj. sił świata duchowego (= altruistycznego), a także - w perspektywie antropologicznej - kolejne kroki przezwyciężania przez człowieka swoich egoistycznych skłonności.

\section{b) dzień drugi}

Drugi dzień stworzenia, opisywany we fragmencie: I rzekt Bóg: „Niech będzie przestwór w pośrodku wód, a niech przedzieli między wodami a wodami!", I uczynił Bóg przestwór i przedzielit między wodami, które pod przestworem, a wodami, które nad przestworem. I stało sie tak, I nazwat Bóg przestwór niebem. I byt wieczór $i$ był ranek - dzień wtóry (Rdz 1:6-8), mówi według Bnei Baruch o tym, że proces naprawy możliwy staje się (po oddzieleniu w dniu pierwszym wewnątrz siebie właściwości egoistycznych od altruistycznych) dzięki Stwórczemu światłu. Stwórca wyemanowuje dwa rodzaje światła - światło Chochmy (światło Mądrości)

\footnotetext{
45 Zob. tamże, s. 11-12.

46 Zob. M. Laitman, The Secret Meaning of the Bible: Seven Days of Creation, art. cyt. (23.11.2014).
} 
i światło Chasidim (światło Miłosierdzia). To używając właściwości tego drugiego światła - zwanego w biblijnych wersetach „wodą" - człowiek wzmacniać ma właściwość altruistyczną, redukując egoizm, tym samym osiągać ma możliwość poczucia wyższego świata (Stwórcy). Woda drugiego dnia stworzenia, jako światło Stwórcy, to zatem właściwość obdarowywania. Ta „stwórcza” woda nasyca ziemię i umożliwia zastanie na niej życia.

\section{c) dzień trzeci}

Wersety I rzekt Bóg: „Niech sie zbiora wody z pod nieba w jedno miejsce, a niech się ukaże lad!" I stało się tak. I nazwat Bóg ląd ziemia, a zbiór wód nazwał morzami. I widział Bóg, że dobrze. I rzekt Bóg: „Niech porośnie ziemia roślina, zielem rozsiewajacem nasienie, drzewem owocowem, rodzacem owoc podtug rodzaju swojego, w któremby nasienie jego było, na ziemi!" I stało się tak. I wydała ziemia rośline - ziele, rozsiewajace nasienie podtug rodzaju swojego i drzewo rodzace owoc, w którem nasienie jego było, podtug rodzaju swojego. I widział Bóg, ze dobrze. I był wieczór $i$ był ranek - dzień trzeci. (Rdz 1:9-1:13) interpretowane są przez Bnei Baruch na sposób mówiący o tym, że woda (altruizm, właściwość Stwórcy) „naprawia” ziemię (egoizm, właściwość ludzką), co umożliwia nastanie na tej drugiej życia (wpierw, tzn. w „trzecim dniu”, roślinnego). Ziemia „pod wpływem" wody zawiera teraz właściwości i otrzymywania (swoje własne), i obdarowywania (wody). Dokładniej rzecz biorac, prawidtowa kombinacja altruistycznych i egoistycznych wlaściwości „nieba” $i$,ziemi” wewnattrz ludzkiej duszy tworzy podstawe dla [własnej - ...] naprawy i przejawiania właściwości Stwórcy wewnatrz człowieka ${ }^{47}$. Słowa a niech sie ukaże lad! ( $\left.\mathrm{Rdz} 1: 9\right)$ wskazują na uświadomienie sobie „faktu” składania się z właściwości przeciwstawnych do Stwórcy - pragnien egoistycznych (tj. z ,ziemi”/, „lądu”).

Naprawa i idealna kombinacja (równowaga), o których mówi się wyżej, zwane są Kav Emtzai („Linia Środkowa”) 48 - w analogii do tego, że życie nie może istnieć ani wyłącznie o wodzie, ani gdy istnieje tylko suchy ląd. Przyrodzony ludziom egoizm to natomiast linia lewa („linia ziemi”), z kolei właściwość identyczna ze Stwórcą (altruizm, woda, niebo ${ }^{49}$ ) to linia prawa ${ }^{50}$. Ludziom zaleca się tzw. pracę z linią środkową, tj. równoważenie przyrodzonej im i jednoznacznej z ich naturą

\footnotetext{
47 Tamże (30.11.2014).

48 Zob. tamże (23.11.2014).

49 Wydaje się, że niebo nie bez przyczyny wiązane jest w nauczaniu Bnei Baruch z wodą. Biblijne niebiosa to wszak „wody górne” (zob. cytowany wcześniej fragment 1:6-8 Księgi Rodzaju). 50 Warto w tym miejscu zauważyć, że linie te to postfiguracja klasycznego kabalistycznego wyobrażenia „drzewa życia” (ec chajim) - składającego się z trzech amudim (kolumn-linii).
} 
chęci otrzymywania właściwościami altruistyczymi ${ }^{51}$. Owo równoważenie jakości to „wybranie życia” - wydanie owocu, nastanie życia (roślinności z opisu stworzenia), co umożliwia i w czym pomaga „woda” (światło Miłosierdzia), która nawadnia ziemię, stwarzając warunki do powstania życia. Wydanie przez ziemię roślinności oznacza pojawienie się pierwszych „kiełków” obdarzania - celem przezwyciężenia przez człowieka egoizmu i powrotu do Stwórcy (naprawy).

\section{d) dzień czwarty}

Czwarty dzień, opisywany w słowach Biblii: I rzekt Bóg: „Niech będa światła na przestworze nieba, aby przedzielać między dniem a noca; a niech stuża jako znamiona i pory $i$ dni i lata; I niech będa światłami na przestworze nieba, dla przyświecania ziemi!" I stało się tak. I utworzył Bóg dwa owe światla wielkie: światło większe dla panowania dniem, a światło mniejsze dla panowania noca, i gwiazdy. I umieścit je Bóg na przestworze nieba, dla przyświecania ziemi. I aby panować dniem i noca i przedzielać między świattem a ciemnościa. I widział Bóg, że dobrze. I był wieczór $i$ był ranek - dzień czwarty ( $\mathrm{Rdz}$ 1:14-1:19), potwierdzać ma zachodzenie naprawy w każdym przejawie stworzenia - tak indywidualnie (Bnei Adam [„synowie Adama”] - wymiar indywidualnych dusz), jak i zbiorowo (całość stworzenia - Adam, dusza). Stworzenie ciał niebieskich („świateł”: słońca i księżyca) dać miało początek mierzalnym okresom naprawy (dni, miesiące, lata), którym podlegają zarówno jednostki (Bnei Adam), jak i ogół stworzenia (Adam) ${ }^{52}$.

Stworzone czwartego dnia ciała niebieskie kierować mają wewnętrznymi stanami człowieka podążającego ku Stwórcy - tzn. „dniem” (stanem wzniesienia; stanem, w którym człowiek jest przekonany o słuszności wybranej drogi) i „nocą” (stanem upadku; stanem, w którym trudno jest osiągnąć „duchowe” i wydaje się ono wręcz iluzją $\left.{ }^{53}\right)$. Z kolei zapis o występowaniu ciał niebieskich na niebie i oświetlaniu ziemi ( $\mathrm{Rdz}$ 1:15: I niech będa światłami na przestworze nieba, dla przyświecania ziemi!) mówić ma o „podporządkowywaniu” się pragnień niskich (egoistycznych), tj. ziemi, właściwości altruistycznej w człowieku - tj. niebu (właściwości Stwórcy). Ciała niebieskie na sklepieniu niebios świecą nad ziemią ( $\operatorname{Rdz} 1: 17:$ I umieścit je Bóg na przestworze nieba, dla przyświecania ziemi), co oznaczać ma, że świecą one nad egoizmem, „naprawiając” go, a rządzenie ich

\footnotetext{
51 Więcej o „pracy wzdłuż trzech linii” zob.: Michael Laitman, Attaining the Worlds Beyond: A Guide to Spiritual Discovery, ed. Benzion Giertz, Laitman Kabbalah Publishers, Toronto 2003, s. $415-423$.

52 Zob. tenże, The Secret Meaning of the Bible: Seven Days of Creation, art. cyt. (30.11.2014).

53 Nieco więcej o owych stanach zob.: tenże, Attaining the Worlds Beyond: A Guide to Spiritual Discovery, wyd. cyt., s. 174, 428-429.
} 
nad dniem i nocą i oddzielanie światłości od ciemności ( $\operatorname{Rdz}$ 1:18: I aby panować dniem $i$ noca $i$ przedzielać między świattem a ciemnościa) wskazuje na panowanie nad stanami wzlotów (dzień) i upadków (noc) człowieka, tj. wskazuje w istocie na możliwość wpływu na owe stany - bo możliwość oddzielania, „przedzielania” jednych od drugich (tj. ,przedzielenia między światłem a ciemnością” [Rdz 1:18]). Stąd tė̇ fragment a niech stuża jako znamiona $i$ pory $i$ dni i lata (Rdz 1:14) mówi o zmianie stanów wewnątrz człowieka na drodze jego duchowego rozwoju - nie twierdzi tym samym o rzeczywistej sekwencji odcinków czasowych. Dzień symbolizuje [...] zmiane stanów wzniesienia $i$ upadku w granicach jednego stopnia ( „poranek”, „dzien””, „wieczór”- to „jeden dzień”) przed przejściem na nastepny stopień... Miesiac (po hebrajsku „hodesz” od słowa „mithadesz”, co znaczy „odnowienie") symbolizuje powrót do poprzedniego stanu, lecz na innym, wyższym, odnowionym poziomie. Już minęlo trzydzieści wzniesień $i$ upadków upadków... Za każdym razem otrzymujesz dodatkowa prace nad swoim egoizmem, spadasz, radzisz sobie i ponownie wspinasz sie po drabinie... Rok („szana” od stowa „leszanen”- „powrót”) - to jakby ruch spiralny, powrót do tego samego stanu, ale na wyższym poziomie. Tak czy owak, wspinasz się do góry ${ }^{54}$.

\section{e) dzień piąty}

I rzekt Bóg: „Niech się zaroja wody rojem jestestw żyjacych, a ptactwo niech się unosi nad ziemia, na przestworze niebios!" I stworzył Bóg owe potwory wielkie $i$ wszelkie jestestwo żyjace, poruszajace się, którem zaroiły się wody podtug rodzaju swego, i wszelkie ptactwo skrzydlate podtug rodzaju swojego. I widział Bóg, że dobrze. I pobłogosławit im Bóg i rzekt: „Rozradzajcie się i rozmnażajcie i napelniajcie wody w morzach, a ptactwo niech się rozmnaża na ziemi!" I był wieczór $i$ byt ranek - dzień piaty. ( $\mathrm{Rdz} 1: 20-1: 23)$.

Powyższy fragment interpretowany jest przez Bnei Baruch jako mówiący o tym, że różne formy życia - jako części stworzenia (a więc chęci/atrybutu otrzymywania) - powstałe dnia piątego, to rezultat połączenia się atrybutu obdarowywania/altruizmu (wody) z atrybutem otrzymywania/egoizmu (ziemią).

Ryby i ptaki powstałe dnia piątego mają być siłami Stwórcy w ,języku gałęzi". Są to jednocześnie właściwości i działania, które powinien przyswoić sobie człowiek w swojej drodze naprawy-powrotu do Stwórcy. Przykładowo, słowo „ryba” to hebrajskie $d a g$, które wywodzone jest od daaga - 'troska'55. Ryba zatem wskazuje na atrybut troski o upodobnienie się do Stwórcy, który to atrybut

54 Tenże, Odkrycie tajemnic Biblii. Od stworzenia do Abrahama, wyd. cyt., s. 24.

55 Zob. tamże, s. 25. 
człowiek winien w sobie zaszczepić (dodatkowo: to, że ryba pływa w wodzie tj. w świetle Miłosierdzia - oznaczać ma, że troska związana jest z cechą miłosierdzia właśnie, a że jest to światło Stwórcy, to jest to atrybut Boga, właściwość altruistyczna) ${ }^{56}$. Z kolei ptaki latające nad ziemią (Rdz 1:20: a ptactwo niech się unosi nad ziemia, na przestworze niebios!) oznaczają Boską właściwość (a więc altruizm) stykającą się z ludzką cechą egoizmu (ziemią), przy czym to za jej (tej pierwszej) pomocą chęć otrzymywania może zostać naprawiona (co wyrażają słowa z Rdz 1:22: a ptactwo niech sie rozmnaża na ziemi!). W istocie rzeczy chodzi tu o wyodrębnienie w sobie takich pragnień egoistycznych, do których można dołączyć altruistyczną intencję, aby te pierwsze naprawić.

\section{f) dzień szósty}

Dnia szóstego według dosłownej interpretacji powstają dalsze gatunki zwierząt oraz człowiek: I rzekł Bóg: „Niech wyda ziemia jestestwa żyjace podtug rodzajów swoich: bydło i płazy i zwierzęta ladowe podtug rodzajów swoich!" I stało sie tak. I utworzył Bóg zwierzęta lądowe podług rodzajów swoich, i było podtug rodzaju swojego, i wszelki płaz ziemny podług rodzaju swojego. I widział Bóg, że dobrze. I rzekt Bóg: „Uczyńmy ludzi na obraz Nasz i podtug podobieństwa Naszego, a niech panuja nad rybami morza, i nad ptactwem nieba, i nad bydlem, i nad wszystka ziemia, i nad wszelkim płazem, który petza po ziemi!" I stworzył Bóg człowieka na obraz Swój, na obraz Boga stworzył go; mężczyzne i niewiaste stworzyt ich. I błogosławit im Bóg, i rzekt do nich Bóg: „Rozradzajcie się i rozmnażajcie, i napetniajcie ziemie, $i$ zawtadnijcie nia, i panujcie nad rybami morza, $i$ nad ptactwem nieba, i nad wszelkim zwierzem, który sie porusza na ziemi!” I rzekt Bóg: „Oto oddaje wam wszelkie ziele rozsiewajace nasienie, będace na powierzchni całej ziemi, $i$ wszelkie drzewo, na którem jest owoc drzewny, rozsiewajacy nasienie: wam niechaj będa na pokarm. A wszelkiemu zwierzowi ladowemu, $i$ wszelkiemu ptactwu nieba, i wszystkiemu, co sie porusza na ziemi, w którem jest dusza żyjaca - wszelka zielona rośline - na pokarm!" I stało się tak. I obejrzat Bóg, wszystko, co uczynit, $i$ oto było bardzo dobre. I był wieczór i byt ranek - dzień szósty. (Rdz 1:24-1:31).

Dla Bnei Baruch kluczowe jest tu stworzenie człowieka na obraz Boga - w języku hebrajskim Be Celem Elochim Bara ${ }^{57}$. Celem wskazuje na część atrybutu obdarowywania-Biny, która wnika w ludzką duszę i przekazuje jej, „zasila” ją

56 W tym miejscu warto wspomnieć, że w pracy XVI-wiecznego kabalisty Mosze Kordowera pt. Tomer Dewora [wyd. polskie: Palma Dewory, przeł. Joanna Białek, Sacha Pecaric, Stowarzyszenie PARDES, Kraków 2007] mówi się o czymś podobnym - o idei „zaszczepiania” w sobie przez człowieka atrybutów Boga (jako Boskie atrybuty traktowanych jest dziesięć sefirot).

57 Zob. M. Laitman, The Secret Meaning of the Bible: Seven Days of Creation, art. cyt. (23.11.2014). Dokładniej rzecz biorąc: "na obraz (celem) i podobieństwo (demut)". 
w atrybut samego Stwórcy (obdarowywania właśnie). W żargonie kabalistycznym mówi się, że z Biny (sefiry) - w której wszystko się zaczyna - emanuje w Malchut (całość ludzkich dusz wymagających naprawy) specjalna jakość-instrument (hebr. celem). Bina (altruizm) naprawia zatem Malchut (egoizm) - człowieka ${ }^{58}$. Hebr. celem ('obraz') to właśnie ów system, w którym poszczególne dusze ze struktury Malchut otrzymują pomoc od Biny-jakości Stwórcy. Stąd człowiek został stworzony na Boży obraz - bo posiada część Biny.

Samo imię Adam wiązane jest ze słowem adamah z biblijnego wersetu Księgi Izajasza 14:14 (gdzie padają słowa Adameh la Elyon - „zrównam się z Najwyższym"), które wskazywać ma na podobieństwo Adama do Stwórcy ${ }^{59}$.

Ponadto, szósty dzień stworzenia jest etapem pracy z silniejszymi pragnieniami egoistycznymi - „wyrosłymi” z ziemi, „zrodzonymi” przez ziemię (dzień piąty charakteryzowany był przez tzw. lżejsze pragnienia egoistyczne). Kulminacją jest „powstanie człowieka”, tzn. narodzenie się „człowieka” wewnątrz osoby. Taki wewnętrzny człowiek oznacza umiejętność panowania nad wszelkimi pragnieniami egoistycznymi ( $\mathrm{Rdz}$ 1:26: I rzekl Bóg: „Uczyńmy ludzi na obraz Nasz i podtug podobieństwa Naszego, a niech panuja nad rybami morza, i nad ptactwem nieba, i nad bydtem, i nad wszystka ziemia, i nad wszelkim plazem, który pełza po ziemi!") - osiągnięcie stanu człowieka jest więc celem i ideałem.

\section{g) dzień siódmy}

Sześć dni stworzenia to etapy ludzkiej naprawy przyjmujące nazwy sześciu sefirot: Chesed, Gewura, Tiferet, Necach, Hod, Jesod. Sefira Jesod „wiąże” wcześniejszych pięć „dni” i jako taka staje się „Fundamentem” (nota bene to właśnie oznacza słowo jesod) dla stworzenia człowieka w dniu szóstym ${ }^{60}$. Sefira dziesiąta (Malchut) - czyli całość ludzkich dusz, stworzenie/Adam par excellence - sama z siebie nie jest w stanie ulec naprawie, ale umożliwia jej to napływ z Biny oraz absorpcja właściwości sześciu wyższych sefirot. Stąd siódmy dzień stworzenia będący dniem Boskiego odpoczynku, tj. szabatem (Rdz 2:2: I skończył Bóg dnia siódmego dzieło Swoje, które uczynit, i odpoczą dnia siódmego po całem dziele Swojem, które uczynił.) dla człowieka jest etapem wspinania się coraz wyżej w swojej naprawie: wszystko, co zostało stworzone i zebrane w sześciu dniach, wnika w Malchut. Dnia siódmego (na siódmym etapie naprawy) dusza ludzka wypełniona zostaje Stwórczym światłem. Człowiek winien jedynie nie powstrzymywać tego procesu, nie

58 Owa struktura ontyczna całości dusz (= ludzi) to tzw. Malchut z Ein-Sof.

59 Zob. M. Laitman, Disclosing a Portion: The Inner Mechanics of the Torah, wyd. cyt., s. 12.

60 Zob. tamże, s. 12. 
przeszkadzać mu i pozwolić mu wydarzyć się - czego symbolicznym wyrazem są prawa szabatu, a dokładniej nakaz „święcenia dnia świętego” (czyli w praktyce powstrzymywanie się od wykonywania wielu czynności).

Sześć dni - 6000 tysięcy lat 61 - to więc ścieżka, którą podąża ludzkość w swoim rozwoju-naprawie. Siódmy dzień to stan na drodze tikkun, który wieńczy proces doskonalenia się. Siódmy dzień to tzw. siódme tysiąclecie - stan, w którym światło Stwórcy całkowicie wypełnia naprawione właściwości stworzenia ${ }^{62}$. Ten etap finalny to stan, w którym wszyscy ludzie "zjednoczą się ponownie w jedną duszę" ${ }^{63}$; to moment, w którym człowiek osiągnie pełne, najwyższe światło (or chochma). Jest to [...] „Światło, które zostało stworzone w pierwszym dniu stworzenia, w którym (świetle) pierwszy człowiek spojrzał z jednego krańca świata na drugi”; a w Kabale mówi się: „na poczatku stworzenia wszystko pochtaniało najwyższe Światło"64. W tym ostatnim etapie, tj. w siódmym tysiącleciu (szabacie), ludzkość naprawić się ma świadomie i dobrowolnie. Według Bnei Baruch ludzkość wkroczyła już na świadomy etap naprawy, a było to w roku 1995 (według kalendarza żydowskiego w roku 5755) 65 - nota bene jest to rok powołania do życia Instytutu Studiów i Badań Kabały Bnei Baruch.

\section{Podsumowanie}

Z ukazanej optyki dni kreacji biblijnego opisu stworzenia, którą prezentuje organizacja Bnei Baruch widać jasno, że jest to optyka, która nie ma nic wspólnego z zapisem dosłownym tej relacji oraz z tradycyjną, ogólnie znaną interpretacją egzegetów teologicznych (żydowskich i chrześcijańskich).

Wydaje się, że interpretacja Bnei Baruch dostosowana została do proponowanego przez organizacje nauczania. Asocjacja biblijnych słów i całego opisu stworzenia z fundamentalnymi kategoriami doktryny Bnei Baruch ma, jak sądzę, za zadanie uwierzytelnić propagowane nauczanie z całością pojawiających się tu

61 Etapy naprawy określane bowiem są też - jeśli nie sześcioma dniami - sześcioma tysiącleciami stworzenia. Przy tej okazji warto powiedzieć, że koncepcja wielkich kosmicznych cykli (eonów) stworzenia jest głęboko kabalistyczna. Noszą one w kabale nazwę szemittot (l.poj. - szemita). Doktryna ta zależna pozostaje od motywów hagadycznych, a swoje eksplicytne wyłożenie odnajduje w pochodzaccej z XIII wieku Sefer ha-Temuna [Ksiega Obrazu] (przypisywanej nierzadko autorstwu Nechunji ben ha-Kana), gdzie zastosowana została do przedstawienia idei cykli kreacji. Sefer ha-Temuna została pierwotnie opublikowana w Korcu w 1784 r.

62 Zob. M. Laitman, The Path of Kabbalah, wyd. cyt., s. 321.

63 Tenże, Disclosing a Portion: The Inner Mechanics of the Torah, wyd. cyt., s. 17.

64 Tenże, Attaining the Worlds Beyond: A Guide to Spiritual Discovery, wyd. cyt., s. 138.

65 Zob. tenże, The Path of Kabbalah, wyd. cyt., s. 322. 
idei. Jest to perspektywa interesująca, jakkolwiek posługiwanie się przez członków organizacji terminem „kabała” na oznaczanie swojego „systemu koncepcyjnego” jest według mnie nadużyciem semantycznym, ponieważ przedstawiane nauczanie wykazuje w istocie bardzo niewielki związek z rzeczywistą kabałą - mistyczno-filozoficzną szkołą judaizmu - i jej twierdzeniami.

\title{
Biblical creation account in Bnei Baruch's teaching
}

\begin{abstract}
Summary
In the paper I present the Bnei Baruch's interpretation of the biblical story of creation (from the Book of Genesis), especially of the category of the "days of creation". This doctrine is a small part of the whole system of Bnei Baruch "Kabbalah". The commentary of the creation account is radically different from the classical theological interpretation. Bnei Baruch's optics is the example of an nonliteral exegesis, but even in this one can clearly see its exceptionality. The key-categories around which the whole interpretation is focused are the ideas - in some way philosophical and psychological - of the "will to receive" (egoism) and the "will to bestow" (altruism). The "days of creation" characterize here the process of human correction, they are the stages of the tikkun, where the final stage is the so-called equivalence of form with the Creator. According to Bnei Baruch, the biblical words do not describe the physical world but deal with the "upper" reality - the spirituality. On the strength of this statement it is said that the language the whole Bible is written in is the "language of the branches" (while the spiritual realm is the root).
\end{abstract}

Key words: Bnei Baruch, Kabbalah, creation story, days of creation, Book of Genesis

Słowa kluczowe: Bnei Baruch, Kabała, opowieść o stworzeniu, dni stworzenia, Księga Rodzaju

\section{Bibliografia}

Aviezer N., Fossils and Faith: Understanding Torah and Science, KTAV Publishing House, Inc, New Jersey: Hoboken 2001.

Aviezer N., In the Beginning: Biblical Creation and Science, KTAV Publishing House, Inc, New Jersey: Hoboken 1990.

Bereszit/Genesis, przeł. I. Cylkow, Kraków 1895.

Ciesielski M., Pomiędzy teizmem i ateizmem. O Bogu, który byt, „Humaniora. Czasopismo Internetowe", nr 2(6)/2014, s. 27-37.

Heidegger M., Identität und Differenz, Günther Neske, Pfullingen 1957. 
Heidegger M., Identyczność i różnica, przeł. J. Mizera, Wydawnictwo Aletheia, Warszawa 2010.

Kordowero Mosze, Palma Dewory, przeł. J. Białek, S. Pecaric, Stowarzyszenie PARDES, Kraków 2007.

Kunicki Z., Teo-ontologia wobec onto-teologii. Étienne Gilsona metafizyka „Ksiegi Wyjścia” na tle wspólczesnych sporów teistycznych, Studio Poligrafii Komputerowej „SQL", Olsztyn 2004.

Laitman M., A Guide to the Hidden Wisdom of Kabbalah, Laitman Kabbalah Publishers, Toronto 2009.

Laitman M., Attaining the Worlds Beyond: A Guide to Spiritual Discovery, B. Giertz (ed.), Laitman Kabbalah Publishers, Toronto 2003.

Laitman M., Basic Concepts in Kabbalah: Expanding Your Inner Vision, transl. D. Brushin, Laitman Kabbalah Publishers, Toronto 2006.

Laitman M., Disclosing a Portion: The Inner Mechanics of the Torah, transl. Ch. Ratz, Laitman Kabbalah Publishers, Toronto 2014.

Laitman M., Kabała ujawniona. Jak doprowadzić nas do świata pokoju, harmonii i ekorozwoju, przeł. A. Wojtaszczyk, Studio Emka, Warszawa 2009.

Laitman M., Kabbalah for Beginners, Laitman Kabbalah Publishers, Toronto 2007.

Laitman M., Kabbalah, Science and the Meaning of Life, transl. Ch. Ratz, Laitman Kabbalah Publishers, Toronto 2006.

Laitman M., The Kabbalah Experience, transl. D. Brushin, Ch. Ratz, Laitman Kabbalah Publishers, Toronto 2005.

Laitman M., The Path of Kabbalah, transl. Ch. Ratz, Laitman Kabbalah Publishers, Toronto 2005.

Mopsik Ch., Kabała, przeł. A. Szymanowski, Wydawnictwo Cyklady, Warszawa 2001.

Schaya L., The Universal Meaning of the Kabbalah, transl. N. Pearson, Penguin Books, Baltimore, Maryland 1973.

Silver A., Jews, Myth and History: A Critical Exploration of Contemporary Jewish Beliefs and Its Origins, Matador, Leicester 2008.

Swieżawski S., Dzieje filozofii europejskiej XV wieku. Tom IV: Bóg, Collectanea Theologica, Warszawa 1979

Wach J., Socjologia religii, przeł. Z. Poniatowski, B. Wolniewicz, Książka i Wiedza, Warszawa 1961.

\section{Źródła internetowe}

About Bnei Baruch, http://www.kabbalah.info/engkab/abouteng.htm.

Laitman M., The Secret Meaning of the Bible: Seven Days of Creation, http://www. kabbalah.info/eng/content/view/frame/2373?/eng/\&main. 
Laitman M., Semion Winokur S., Odkrycie tajemnic Biblii. Od stworzenia do Abrahama, http://files.eurokab.info/pl/Odkrycie\%20tajemnic\%20Biblii-1.pdf.

Piotrowski R., Tora i nauka wedtug Aviezera (rec.), „Filozoficzne Aspekty Genezy”, 2012, t. 9, s. 277-282, http://www.nauka-a-religia.uz.zgora.pl/images/FAG/2012. t.9/art.11.pdf.

Schwartz H., How the Ari Created a Myth and Transformed Judaism, http://www.tikkun. org/nextgen/how-the-ari-created-a-myth-and-transformed-judaism.

Mgr Dorota Brylla, Uniwersytet Zielonogórski, Wydział Humanistyczny, Instytut Filozofii, Zakład Ontologii i Teorii Poznania; al. Wojska Polskiego 71A, 65-762 Zielona Góra; e-mail: d.brylla@ifil.uz.zgora.pl 